\section{References}

Burton, C. \& Johnson, J. (1970) Multiple cerebral aneurysms and cardiac tumours. New English Journal of Medicine, 282, 35 .

DAvis, E. (1970) Criterion for diagnosis of rheumatic fever. Lancet, i, 1043.

Edler, I. \& Hertz, C.H. (1954) The use of ultra-sound reflectoscope for the continuous recording of heart walls. Kungliga Fysiografifk Sallskapts $i$ Lund. Forhandlingar, 24, 5.

Effert, S. \& Domanig, E. (1959) The diagnosis of intra atrial tumours and thrombi by the ultra-sonic echo method. German Medical Monthly, 4, 1.

GoodwiN, J.F. (1964) Diagnosis of left atrial myxoma. Lancet, i, 464.

Goodwin, J.F., Stanfield, C.A., Steiner, R.E., Bentall, H.H., SAYed, H.M., Gloom, V.R. \& Bishop, M.B. (1962) Clinical features of left atrial myxoma. Thorax, 17, 91.

GoodwIN, J.F. (1968) The spectrum of cardiac tumours. American Journal of Cardiology, 21, 307.
Harvey, J.C. (1957) Myxoma of the left auricle. Annals of Internal Medicine, 47, 1067.

Heath, D. (1968) Pathology of cardiac tumours. American Journal of Cardiology, 21, 315.

Kroopf, S.S. \& Peterson, C.A. (1957) Anaplastic myxoma of left atrium, A.M.A. Archives of internal medicine, 100, 819.

Nadas, A.S. \& Curtis-Ellison, R. (1968) Cardiac tumours in infancy. American Journal of Cardiology, 21, 363.

PoPP, R.L. \& Harrison, D.C. (1969) Ultra-sound for the diagnosis of atrial tumours. Annals of Internal Medicine, 71, 785.

SChattenberG, T.T. (1968) Echocardiographic diagnosis of left atrial myxoma. Mayo Clinic Proceedings, 43, 620.

Wolff, S.P., Popp, R.L. \& Feigenbaum, H. (1969) Diagnosis of atrial tumours by ultra sound. Circulation, 39, 615.

YATER, W.M. (1931) Tumours of the heart and pericardium. Archives of Internal Medicine, 48, 627.

\title{
Duogastrone-induced hypokalaemic nephropathy and myopathy with myoglobinuria
}

\author{
A. B. S. Mitchell \\ M.B., M.R.C.P. \\ West London Hospital, Charing Cross Group of Hospitals, London, W.6
}

CARBEnoxolone sodium and the parent substance, liquorice, have an aldosterone-like effect, and may give rise to oedema, hypertension and hypokalaemia (Baron \& Nabarro, 1968; Hausmann \& Tarnoky, 1968). The hypokalaemia may cause a myopathy, perhaps with myoglobinuria, or a nephropathy or death. Reports of these complications are listed in Table 1.
Hypokalaemia, with all the above effects apart from death, occurred in a patient while taking positioned-release capsules of carbenoxolone (Duogastrone) in the recommended dose, and within the recommended course duration.

\section{Case report}

N.M., a 46-year-old Pakistani male waiter, who

TABLE 1. List of the reported cases in which complications of hypokalaemia have occurred during therapy with liquorice or its derivatives (Number of patients in each report noted in parenthesis)

\begin{tabular}{|c|c|c|c|c|}
\hline & \multicolumn{2}{|c|}{ Muscle weakness } & \multirow{2}{*}{ Nephropathy } & \multirow{2}{*}{ Death } \\
\hline & Myopathy & With myoglobinuria & & \\
\hline Liquorice preparations & $\begin{array}{l}\text { Cayley (1), 1950; Heard, Camp- } \\
\text { bell \& Hurley (6), 1950; Strong } \\
\text { (2), 1951; Mollaret, Goulon \& } \\
\text { Tournilhac (1), 1960; Garcin } \\
\text { et al. (1), 1961; Giroire et al. (1), } \\
\text { 1961; Jenny et al. (1), 1961; } \\
\text { Salassa, Mattox \& Rosevear (1), } \\
\text { 1962; Chodkiewicz, Clay \& } \\
\text { Hecaen (2), 1963; Minvielle, } \\
\text { Cristol \& Badach (2), 1963; } \\
\text { Holmes et al. (1), 1970 }\end{array}$ & $\begin{array}{l}\text { Geerling (1), 1966; Gross, } \\
\text { Dexter \& Roth (1), } 1966\end{array}$ & $\begin{array}{l}\text { Chodkiewicz } \\
\text { et al. (1), } 1963\end{array}$ & $\begin{array}{l}\text { Heard et al. (4), } \\
1950^{*} \text {; Roussak } \\
(1), 1952\end{array}$ \\
\hline $\begin{array}{l}\text { Carbenoxolone sodium: } \\
\text { as Biogastrone } \\
\text { as Duogastrone }\end{array}$ & $\begin{array}{l}\text { Morgan, Donald \& McAndrew } \\
\text { (1), } 1966 \dagger \\
\text { Muir, Laithwaite \& Wood (1), } \\
1969\end{array}$ & $\begin{array}{l}\text { Mohamed, Chapman \& } \\
\text { Crooks (1), } 1966 \\
\text { Forshaw (1), } 1969 \ddagger\end{array}$ & & \\
\hline
\end{tabular}


had lived in England for 7 years, had suffered from dyspepsia since 1965. A barium meal at that time was said to show no abnormality. A repeat radiological examination in July 1969 revealed a deformed irritable duodenal cap containing a small ulcer crater. Antacids and a gastric diet effected no improvement, and in November 1969, Duogastrone $200 \mathrm{mg}$ daily was prescribed.

His dyspeptic symptoms disappeared after a few weeks. In the fourth week of treatment he developed polydipsia and polyuria with nocturia three or four times nocte. During the following week he developed generalized muscle weakness. An injection of vitamin $B_{12}$ led to temporary improvement, but, in the sixth week after starting Duogastrone therapy, he was referred to the West London Hospital for the first time because of increasing weakness and pain in his muscles on attempted movement. He had stopped taking Duogastrone on his own initiative 3 days before being seen. There were no other relevant facts in his past or present history, and his family history was non-contributory.

On examination he appeared an ill and anxious man. There was no oedema. Blood pressure 140/80 $\mathrm{mmHg}$. Deep tenderness was elicited in the epigastrium. There was profound weakness of all muscles, especially of the proximal muscle groups which were tender. All the tendon jerks were brisk, plantar responses flexor. No abnormality of sensation was found.

Investigations performed on the day of presentation were as follows: The serum electrolytes $(\mathrm{mEq} / \mathrm{l})$ were: potassium $1 \cdot 7, \mathrm{CO}_{2} 40$, sodium 142 . The blood urea was $20 \mathrm{mg} / 100 \mathrm{ml}$. An electrocardiogram showed marked hypokalaemic changes.

The urine was light yellow. On reagent-impregnated test strips ('Labstix', Ames), a strongly positive reaction for protein and blood, and an alkaline reaction, were found. No red or white blood cells or other formed elements were seen on microscopy. Spectroscopy revealed a faint band at the wave length for myoglobin. Urinary electrolyte concentrations $(\mathrm{mEq} / \mathrm{l})$ were: potassium 40 , sodium 58.

Serum aspartate and alanine aminotransferase activities were 155 and $130 \mathrm{IU} / 1$ respectively, serum creatine phosphokinase activity was 2980 IU/l (normal upper limits 12, 10, and 40-60 IU/1, respectively).

Serum bilirubin concentration was $1.2 \mathrm{mg} / 100 \mathrm{ml}$, alkaline phosphatase activity $16 \mathrm{KA}$ units. Total serum protein concentration was $7.6 \mathrm{~g} / 100 \mathrm{ml}$, serum albumin $3.8 \mathrm{~g} / 100 \mathrm{ml}$. Serum calcium $8.8 \mathrm{mg} / 100 \mathrm{ml}$ (normal range $9 \cdot 1-10 \cdot 6 \mathrm{mg} / 100 \mathrm{ml}$ ) 1 . $\mathrm{Hb} 15.6 \mathrm{~g} / 100$ $\mathrm{ml}, \mathrm{WBC} 7600 / \mathrm{mm}^{3}$, and the ESR was $11 \mathrm{~mm}$ in the first hour (Westergren). No abnormality was seen on an X-ray of his chest.
A retrospective analysis of his gastric diet, modifieg by the patient to include mild curry, showed it to include $80 \mathrm{mEq}$ potassium daily.

Treatment. He was put to bed, and $48 \mathrm{mEq}$ of potassium daily was given to supplement the normali hospital diet. Serial serum electrolyte estimation $\overrightarrow{\bar{s}}$ are shown in Table 2. After a few days he felt strong enough to wish to get up, and was allowed out of bed after a week. After 3 weeks his serum potassunge concentration was near normal, his electrocardio $\$$ gram had returned to normal, his muscle strength had returned, and his muscles were no longer tender? He was discharged on no treatment to convalesce a home, and admitted for re-assessment 4 weeks later $\overrightarrow{.}$ He then returned to work, but was re-assessed as aw in-patient periodically during the following month He remains well and a repeat barium meal showed $\underset{\mathbb{z}}{\mathbf{z}}$ normal duodenal cap, with no evidence of the ulceis seen previously. Following return to work his only complaint was discomfort in his knee joints. Nor clinical or radiological abnormality was found tion account for this complaint, which was probably caused by ligamentous strain resulting from pogf muscle tone.

Serial urinary concentrations and 24-hr outp of electrolytes, urea and creatinine are shown

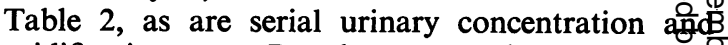
acidification tests. Renal concentrating ability wasp tested by measuring the specific gravity of successeye. urine specimens after the administration of 7 Pitressin (Sodeman \& Engelhardt, 1943). The abi啇y of the kidney to acidify urine was tested by measuring the $\mathrm{pH}$ of successive urine specimens following ans ammonium chloride load (Wrong \& Davies, 1959).

Progress. The urinary acidification test returneकः to normal by 6 weeks, by which time the urinary concentration test had improved, only returning t $\vec{\delta}$ normal some time later. The urinary creatinine excretion increased, but the creatinine clearance was still subnormal after nearly 6 months. An intra? venous pyelogram was normal. A renal biopsy then showed changes of a membranous nephropathy. together with conspicuous, but patchy, interstitia fibrosis with considerable tubular atrophy.

Albuminuria disappeared 3 days after admission, and myoglobinuria was not found again. Repeated microscopic and bacteriological examinations of the urine have remained normal.

Both the aspartate and alanine aminotransferase activity were still raised, being 115 and $135 \mathrm{IU} / \mathrm{N}$ respectively, when he was allowed home after 3 weeks: Subsequent estimations have all been normal. Thes serum creatine phosphokinase level fell to $126 \mathrm{IU} / \mathrm{E}$ after 3 weeks, at which time urinary creatine was still present $(10 \mathrm{mg}$ excreted in $24 \mathrm{hr}$ ), but on returmo from 4 weeks' convalescence at home it had risen to 260 IU/l. Subsequent estimations have been norma! 
TABLE 2. Results of serial investigations (see text)

\begin{tabular}{|c|c|c|c|c|c|c|c|}
\hline \multirow{2}{*}{$\begin{array}{l}\text { No. of } \\
\text { days from } \\
\text { presentation }\end{array}$} & \multicolumn{2}{|c|}{$\begin{array}{l}\text { Serum electrolyte } \\
\text { concentration }(\mathrm{mEq} / 1)\end{array}$} & \multicolumn{3}{|c|}{ Urinary constituents } & \multirow{2}{*}{$\begin{array}{c}\begin{array}{c}\text { Urinary } \\
\text { concentration } \\
\text { test }\end{array} \\
\text { Maximal SG }\end{array}$} & \multirow{2}{*}{$\begin{array}{c}\begin{array}{c}\text { Urinary } \\
\text { acidification } \\
\text { test }\end{array} \\
\text { Minimum pH }\end{array}$} \\
\hline & Potassium & $\mathrm{CO}_{2}$ & Potassium & $\begin{array}{c}\text { Urea } \\
\text { (mg/100 ml) }\end{array}$ & $\begin{array}{l}\text { Creatinine } \\
(\mathrm{mg} / 24 \mathrm{hr})\end{array}$ & & \\
\hline 0 & 1.7 & 40 & $40 \mathrm{mEq} / 1$ & 340 & - & - & - \\
\hline 1 & - & - & $52 \mathrm{mEq} / 24 \mathrm{hr}$ & - & - & - & - \\
\hline 2 & - & - & - & - & 435 & - & - \\
\hline 3 & $2 \cdot 1$ & 38 & - & - & - & - & - \\
\hline 7 & 2.8 & 35 & - & - & - & - & - \\
\hline 9 & 3.0 & 33 & - & - & - & 1010 & - \\
\hline 14 & - & - & - & - & - & - & $6 \cdot 7$ \\
\hline 19 & $3 \cdot 4$ & 29 & - & - & - & - & - \\
\hline 20 & $3 \cdot 4$ & 30 & - & - & $\begin{array}{c}1245 \\
\text { (clearance } \\
61 \mathrm{ml} / \mathrm{min} \text { ) }\end{array}$ & - & - \\
\hline 23 & - & - & - & - & - & - & $6 \cdot 3$ \\
\hline 26 & - & - & - & - & - & 1008 & - \\
\hline 48 & $4 \cdot 6$ & 27 & - & - & $\begin{array}{c}1500 \\
\text { (clearance } \\
74 \mathrm{ml} / \mathrm{min} \text { ) }\end{array}$ & - & - \\
\hline 49 & - & - & - & - & - & 1016 & - \\
\hline 50 & - & - & - & - & - & - & 5.5 \\
\hline 92 & 3.9 & 24 & - & - & - & - & - \\
\hline 163 & 3.5 & 24 & $45 \mathrm{mEq} / 24 \mathrm{hr}$ & $\begin{array}{c}1250 \\
(17 \cdot 3 \mathrm{~g} / 24 \mathrm{hr})\end{array}$ & $\begin{array}{c}1540 \\
\text { (clearance } \\
67 \mathrm{ml} / \mathrm{min} \text { ) }\end{array}$ & - & - \\
\hline 179 & 3.5 & 21.5 & $35 \mathrm{mEq} / 24 \mathrm{hr}$ & $\begin{array}{c}2000 \\
(17.6 \mathrm{~g} / 24 \mathrm{hr})\end{array}$ & $\begin{array}{c}1600 \\
\text { (clearance } \\
65 \mathrm{ml} / \mathrm{min} \text { ) }\end{array}$ & 1026 & - \\
\hline
\end{tabular}

and a muscle biopsy confirmed the absence of residual muscle abnormality.

The serum bilirubin level fell to $0.9 \mathrm{mg} / 100 \mathrm{ml}$ after a week, and thereafter remained below $0.5 \mathrm{mg}$ / $100 \mathrm{ml}$. The serum alkaline phosphatase level (KA units) rose to 22 after a week, then to 36 after 3 weeks. The level remained raised, and was 22 after 5 months at which time an estimation of the $5^{\prime}$ nucleotidase level showed this to be elevated to 48 IU/1. The serum alkaline phosphatase level finally returned to normal in the sixth month. A hepatic biopsy then revealed a normal lobular pattern, with a slight increase in histiocytes in the portal tract.

The serum calcium was re-estimated when the serum potassium was normal, and was repeatedly found to be within normal limits, as was the serum inorganic phosphorus concentration. The total serum protein and albumin levels remained normal.

\section{Discussion}

With adequate dietary fluid, food and potassium intake, and no glycolysis, deglycogenation or apparent gastrointestinal source of potassium loss, renal loss of potassium can be assumed to be the cause of hypokalaemia. High urinary potassium concentration and output, despite severe hypokalaemia, were demonstrated on admission, 3 days after the last dose of Duogastrone. Although the action of carbenoxolone is short-lived after absorption (Parke, 1968), the positioned-release capsules are designed to remain intact until burst by gastric antral contractions (Galloway, 1968), and there is evidence that they float in gastric contents and are seldom found in the gastric antrum of patients taking meals (ColinJones et al., 1968). The release of carbenoxolone from the capsules can therefore be delayed, which is the likely explanation for the inappropriately high urinary excretion of potassium still being found on presentation. In the patient described by Forshaw (1969), the onset of hypokalaemic myopathy was delayed until 9 days after the last dose of Duogastrone, probably for the same reason.

No corticosteroids, diuretics or any other drugs had been taken that might have explained the potassium excretion. The patient now maintains a normal serum potassium, without excessive urinary potassium loss, so primary aldosteronism is unlikely, Glomerulonephritis may cause potassium wasting, but not with the minimal renal functional impairment which is present in this patient after potassium replenishment. Potassium depletion may itself give rise to severe renal dysfunction, but most evidence indicates that this does not impair renal conservation of potassium (reviewed in Hollander, 1963). There is only one study which suggests that potassium wasting may then occur (Iacobellis, Muntwyler \& Griffin, 1955).

A nephropathy was suggested on admission by the 
impaired ability to concentrate urine and possibly by the impaired ability to acidify urine. Polyuria and polydipsia resulting from hypokalaemia do not necessarily indicate renal dysfunction, as there is evidence that depletion of potassium may directly stimulate the thirst centre (reviewed in Welt, Hollander \& Blythe, 1960). Polydipsia may itself diminish the kidneys' ability to concentrate urine (de Wardener \& Herxheimer, 1957; Epstein, Kleeman \& Hendriks, 1957 ), and it has been suggested that primary polydipsia may be a factor in producing a concentrating defect in hypokalaemia (Hollander et al., 1957). But it has been demonstrated in rats that impaired concentrating ability is not affected by the level of fluid intake (Blythe et al., 1960), and as many patients do not drink excess water, it is improbable that polydipsia from hypokalaemia is the cause of the concentrating defect (Relman \& Schwartz, 1967). The interpretation of the results of the urinary acidification test in the presence of the patient's metabolic derangement is more difficult, because the result might have been affected by hypokalaemia (Clarke et al., 1955) by the marked water diuresis (Nutbourne \& de Wardener, 1961; Tannen, 1969), and by hypomagnesaemia (Smith et al., 1962) which was possibly present (vide infra). Impaired urinary acidification with hypokalaemia may indicate not a nephropathy but a physiological mechanism of potassium conservation by an increase in ammonium excretion, and resultant increase in urinary $\mathrm{pH}$ (Tannen, 1970). The low urinary urea concentration on admission may perhaps have been due to polyuria; the low creatinine excretion over the next $24 \mathrm{hr}$ is difficult to interpret in view of the presence of muscle necrosis.

Urinary concentration and acidification returned to normal after potassium repletion. This suggests that the nephropathy was the direct result of hypokalaemia. Duogastrone had only been taken for 5 weeks, and symptoms which could be attributed to hypokalaemia had developed only 2 weeks before presentation. The period during which the patient was hypokalaemic was thus short. Virtually nothing is known of the minimum duration and severity of hypokalaemia which will induce significant renal lesions in man. Most patients have been seriously depleted for at least several weeks and usually many months or years (Relman \& Schwartz, 1967), although Stamey (1956) described the finding of histological evidence of hypokalaemic nephropathy in a patient who died 1 week after uterosigmoidoscopy. The ingestion of a liquorice preparation has only once previously been reported to have given rise to hypokalaemic nephropathy, diagnosed because a diuresis of $61 / 24 \mathrm{hr}$ was not responsive to vasopressin (Chodkiewicz, Clay \& Hecaen, 1963). This patient had consumed large quantities of a drink containing liquorice, and had suffered from $\frac{0}{2}$ periodic attacks of muscle weakness for 3 years before ڤ hypokalaemic myopathy and nephropathy were $\frac{\pi}{1}$ diagnosed. The presence of myoglobinuria suggests $\cong$ an alternative cause for the nephropathy, but such a $c$ small amount was present that it can be discounted $\overrightarrow{\vec{F}}$ as a factor in the production of renal impairment. $\frac{\overrightarrow{0}}{0}$

Creatinine clearance remained impaired 5 months $\frac{}{\circ}$ after the serum potassium had been restored to $\overline{\bar{c}}$ normal. Renal biopsy then showed the histological $\vec{\nabla}$ appearances of membranous nephropathy, together with interstitial fibrosis and tubular atrophy. Thises abnormality of the basement membrane has not $\overrightarrow{0}$ previously been described in hypokalaemic nephro- $-\overrightarrow{-}$ pathy and is probably unrelated to it; the other histological changes may just possibly be the resulto of hypokalaemia. Hypokalaemic nephropathy was 3 thought to be completely reversible (Relman $\&_{A}^{-}$ Schwartz, 1956), but might not always be so benign. Progressive renal insufficiency, with no other factory apparent, has followed severe prolonged potassium $\mathrm{i}_{\infty}$

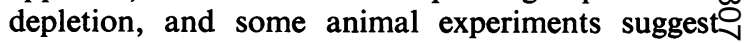
that this may occur (Relman \& Schwartz, 1967).

Hypokalaemic myopathy and myoglobinuria hate been previously described following the ingestion $\overline{\text { Tff }}$ liquorice preparations and derivatives (Table 1). Tfe्f clinical and biochemical conversion of the patienfes muscles to normal following potassium replenishment, together with the then normal muscle his:-logy, indicate that hypokalaemia was the cause $\bar{\beta}$ the myopathy with myoglobinuria. Muscle pain andtenderness were prominent features, and have been noted previously (Heard, Campbell \& Hurley, 1950 ํㅗㄹ Strong, 1951; Giroire et al., 1961; Jenny et al., 1961 긍 Chodkiewicz et al., 1963; Minvielle, Cristol \& Badach, 1963; Morgan, Donald \& McAndrew, 1966 \% Holmes et al., 1970). Pain is not usually regarded as a feature of hypokalaemic myopathy (Thomas, 1968), and does not occur in hypokalaemic familiab periodic paralysis, nor has it been described with: other causes of the hypokalaemia. The pain is due tö muscle necrosis caused by hypokalaemia, an occur 3 rence which, with myocardial necrosis, can be prow duced in animals (Ellis, 1956). The absence cf reports of muscle pain in other causes of hypokalaemis myopathy (excluding hypokalaemic familial periodic paralysis which has a very different pathophysiology? might be because the hypokalaemia is less severe because death intervenes from myocardial damage because the illness of the patient obscures the symptom, or because, if corticosteroid therapy is being given, the inflammatory response is suppressed 0 Muscle necrosis in animals treated with cortico steroids is very similar to that associated with hypokalaemia (Ellis, 1953, 1956), while pain is nof a feature of corticosteroid-induced myopathy in humans (McArdle, 1969). 
The serum calcium concentration on admission was below normal. A low serum calcium has been found previously in these circumstances (Strong, 1951; Roussak, 1952; Gross, Dexter \& Roth, 1966; Muir, Laithwaite \& Wood, 1969; Holmes et al., 1970), and has not been explained. In primary aldosteronism, magnesium excretion in the urine is increased, and in patients with this disease, hypomagnesaemia has been recorded (Mader \& Iseri, 1955; Milne, Meuharche \& Aird, 1957; Hudson, Barnett \& Bernstein, 1957). Hypomagnesaemia is associated with both hypokalaemia and hypocalcaemia (Shils, 1969). Perhaps the aldosterone-like effect of liquorice preparations acts similarly. The serum magnesium level has been estimated in four patients suffering from hypokalaemia induced by liquorice derivatives (Mollaret, Goulon \& Tournilhac, 1960; Minvielle et al., 1963; Muir et al., 1969; Holmes et al., 1970). All estimations have been normal but in only the last two of these was hypocalcaemia present.

The serum bilirubin concentration was found to be raised on admission, as was the alkaline phosphatase activity, which remained abnormal, and was associated with elevated $5^{\prime}$ nucleotidase activity. This indicates hepatic disease. The aminotransferase activity fell to normal before the serum creatine phosphokinase activity, and any elevation due to hepatic disease cannot be distinguished from that due to muscle damage. $5^{\prime}$ nucleotidase activity has not been found to be abnormal in muscle disease (Pennington, 1969). The serum alkaline phosphatase activity returned to within the normal range after 6 months. A liver biopsy then showed normal hepatic architecture and a slight increase of histiocytes in the portal tracts, probably representing resolving inflammation. The hepatic disorder was probably a direct toxic effect of carbenoxolone. Baron \& Nabarro (1968), and Hausmann \& Tarnoky (1968) have demonstrated abnormalities of aminotransferase and alkaline phosphatase activity, and bromsulphalein retention during treatment with carbenoxolone. In their patients, withdrawal of the drug led to prompt return of these tests to normal. Hypokalaemia precipitates hepatic coma (Read et al., 1959), but this is associated with increased ammonium output into the renal vein (Baertl, Sancetta \& Gabuzda, 1963), and with readier penetration of the ammonium ion into the cerebrospinal fluid in the presence of alkalosis (Warren et al., 1960; Moore, Strohmeyer \& Chalmers, 1963), and not with a direct hepatotoxic effect.

Carbenoxolone sodium (Biogastrone) was of no value in treating patients with duodenal as opposed to gastric ulceration (Doll et al., 1962). The way in which carbenoxolone exerts its healing effect on gastric ulcers is unknown. Although it is improbable that similar ulcerogenic factors act in both duodenal and gastric ulcers (Avery Jones, Gummer \& Lennard-Jones, 1968), it was postulated that rapid absorption of carbenoxolone from the stomach prevented it from reaching the duodenum, and prevented a beneficial effect in duodenal ulceration. The positioned-release capsule (Duogastrone) was therefore developed and designed for use by ambulant patients (Galloway, 1968). Clinical trials have given conflicting results. Some double-blind trials have shown a significant advantage in the Duogastrone-treated group (Craig et al., 1968; Hunt, 1968; Amure, 1970), while others have shown no advantage in the test group (Colin-Jones et al., 1968; Cliff \& Milton-Thompson, 1970).

Complications of liquorice preparations and derivatives are commoner in ambulant than in recumbent patients (reviewed in Hausmann \& Tarnoky, 1968), and though uncommon are potentially fatal. It is important to be aware of their occurrence when considering the use of Duogastrone, and especially as its therapeutic efficacy is unproven.

\section{Acknowledgments}

I should like to thank Professor H. E. de Wardener for help with the manuscript. Dr A. Morton Gill kindly allowed me to publish this report on a patient under his care.

\section{References}

Amure, B.O. (1970) Clinical study of Duogastrone in the treatment of duodenal ulcers. Gut, 11, 171.

Avery Jones, F., Gummer, J.W.P. \& Lennard-Jones, J.E. (1968) Peptic ulcer. In: Clinical Gastroenterology, 2nd edn, pp. 469-482. Blackwell Scientific Publications, Oxford.

BaerTl, J.M., Sancetta, S.M. \& Gabuzda, G.J. (1963) Relation of acute potassium depletion to renal ammonia metabolism in patients with cirrhosis. Journal of Clinical Investigation, 42, 696.

Baron, J.H. \& NABARro, J.D.N. (1968) Metabolic studies of carbenoxolone sodium as Biogastrone and Duogastrone in patients with peptic ulcer. In: Symposium on Carbenoxolone Sodium (Ed. by J. M. Robson \& F. M. Sullivan), pp. 127-157. Butterworth, London.

Blythe, W.B., Newton, M., Lazcano, F. \& Welt, L.G. (1960) Effect of water restriction on urinary concentrating ability in potassium-depleted rats. American Journal of Physiology, 199, 912.

CAyley, F.E. DE W. (1950) Potassium deficiency in Paraaminosalicylic acid therapy. Cardiac and paralytic effects. Lancet, i, 447.

Chodkiewicz, J.P., Clay, J. \& Hecaen, H. (1963) Deux nouvelles observations de paralysies avec hypokaliemie secondaire à l'ingestion excessive d'extrait de reglisse chez des ethyliques chroniques. Revue Neurologique, 108, 324.

Clarke, E., Evans, B.M., Macintyre, I. \& Milne, M.D. (1955) Acidosis in experimental electrolyte depletion. Clinical Science, 14, 421.

Cliff, J.M. \& Milton-Thompson, G.J. (1970). A doubleblind trial of carbenoxolone sodium capsules in the treatment of duodenal ulcer. Gut, 11, 167.

Colin-Jones, D.G., LenNaRd-Jones, J.E., Howell-Jones, J., Miziewicz, J.J. \& LaNGMaN, M.J.S. (1968). Carbenoxolone capsules (Duogastrone) in duodenal ulcer: preliminary results of clinical and experimental studies. In: Symposium on Carbenoxolone Sodium (Ed. by J. M. Robson \& F. M. Sullivan), pp. 209-216. Butterworth, London. 
Craig, O., Hunt, T., Kimberling, J.J. \& Parke, D.V. (1967) Carbenoxolone in the treatment of duodenal ulcer. Practitioner, 199, 109.

Doll, R., Hill, I.D., HutTon, C.F. \& UNDERWood, J.D.H. (1962). Clinical trial of a triterpenoid liquorice compound in gastric and duodenal ulcer. Lancet, ii, 793.

ELLIS, J.T. (1953) Studies on the nature and pathogenesis of muscular degeneration in cortisone-treated rabbits. Bulletin of the New York Academy of Medicine, 29, 814.

ELLIS, J.T. (1956) Necrosis and regeneration of skeletal muscles in cortisone treated rabbits. American Journal of Pathology, 32, 993.

Epstein, F.H., Kleeman, C.R. \& HendRicks, A. (1957) The effect of bodily hydration on renal concentrating process. Journal of Clinical Investigation, 36, 629.

Forshaw, J. (1969) Muscle paresis and hypokalaemia after treatment with Duogastrone. British Medical Journal, 2, 674.

Galloway, R. (1968) Development of the Duogastrone capsule. In: Symposium on Carbenoxolone Sodium (Ed. by J. M. Robson \& F. M. Sullivan), pp. 203-208. Butterworth, London.

Garcin, R., Goulon, M., Tournilhac, M. \& AMOR, B. (1961) Nouvelle observation de paralysies avec hypokaliemie et alcalose metabolique secondaires à l'ingestion excessive et prolongée d'extrait de reglisse après cure de desintoxication ethylique. Revue Neurologique, 104, 461.

GeErling, J. (1966) Potassium depletion and myoglobinuria caused by the use of licorice. Nederlandscher Tijdschift Geneeskunde, 110, 1919.

Giroire, H., Charbonnel, P., Verchetto, I. \& Delhumeau, O.C. (1961) Une nouvelle observation de paralysies avec hypokaliemie par ingestion d'extrait de reglisse. Revue Neurologique, 104, 539.

Gross, E.G., Dexter, J.D. \& Roth, R.G. (1966) Hypokalaemic myopathy with myoglobinuria associated with liquorice ingestion. New England Journal of Medicine, 274, 602.

HausmanN, W. \& TARnOKY, A.L. (1968) Clinical biochemical effects of Carbenoxolone. In: Symposium on Carbenoxolone Sodium (Ed. by J. M. Robson \& F. M. Sullivan), pp. 159-172. Butterworth, London.

HeARD, K.H., CAMPBell, A.H. \& HuRLey, J.J. (1950) Hypokalaemia complicating sodium para-aminosalicylate for pulmonary tuberculosis. Medical Journal of Australia, 2, 606 .

Hollander, W., Jr, Winters, R.W., Williams, T.E., Bradley, J., Oliver, J. \& Welt, L.G. (1957) Defect in the renal tubular reabsorption of water associated with potassium depletion in rats. American Journal of Physio$\log y, 189,557$.

Hollander, W., Jr, (1963) In: Diseases of the Kidney (Ed. by M. B. Strauss \& L. G. Welt), pp. 675-711. Churchill, London.

Holmes, A.M., Marrott, P.K., Young, J. \& Prentice, E. (1970) Pseudohyperaldosteronism induced by habitual ingestion of liquorice. Postgraduate Medical Journal, 46, 625.

Hudson, B., BARnetr, A.J. \& Bernstein, J. (1957) Primary aldosteronism. Australian Annals of Medicine, 6, 250.

HuNT, T.C. (1968) Clinical experience with carbenoxolone capsules (Duogastrone) in duodenal ulcer. In: Symposium on Carbenoxolone Sodium (Ed. by J. M. Robson \& F. M. Sullivan), pp. 195-201. Butterworth, London.

IACobellis, M., MunTwYler, E. \& GRIfFIN, G. E. (1955) Kidney glutaminase and carbonic anhydrase activity and tissue electrolyte composition in potassium-deficient dogs. American Journal of Physiology, 183, 395.

JeNNY, M., Muller, A.F., FABRe, J. \& MACH, R.S. (1961) Hypokaliemie et alkalose par ingestion abusive d'extrait de reglisse (liquorice) et d'eau bicarbonatée. Schweizerische Medizinische Wochenschrift, 91, 869.
MADER, I.J. \& Iseru, L.T. (1955) Spontaneous hypopotase्巳 semia, hypomagnesemia, alkalosis and tetany due top hypersecretion of corticosterone-like mineralocorticoid. American Journal of Medicine, 19, 976.

McARDLE, B. (1969) Metabolic and endocrine myopathies. In: Disorders of Voluntary Muscles (Ed. by J. N. Walton),,. 2nd edn, p. 632. Churchill, London.

MILNe, M.D., MeUhrChe, R.C. \& AIRD, I. (1957) Primaryes aldosteronism. Quarterly Journal of Medicine, 26, 317.

Minvielle, J., Cristol, P. \& BADACH, L. (1963) L'abus de reglisse (glycyrrhizine). Expression clinique: paralysies $\overline{\bar{\sigma}}$ avec hypokaliemie ( 2 observations). Hypertension artérielle (25 observations). Discussion physio-pathologique. $\stackrel{\square}{\Omega}$ Presse Médicale, 71, 2021.

Mohamed, S.D., CHapman, R.S. \& Crooks, J. (1966) (ֶ) Hypokalaemia, flaccid quadriparesis and myoglobinuria $\vec{\circ}$ with Carbenoxolone (Biogastrone). British Medicat Journal, 1, 1581.

Mollaret, P., Goulon, M. \& Tournilhac, M. (1960). Quadriplegie avec hypokaliemie et alcalose metabolique्ठ secondaire à l'ingestion massive et prolongée d'extrait dê reglisse chez un psychopathe ethylique et potomane.? Bulletins Mémoires de la Société Médicale Hópitaux duキ Pays, 76, 491.

Moore, E.W., Strohmeyer, G.W. \& Chalmers, T.C. (1963) of Distribution of ammonia across the blood-cerebrospinal ${ }^{+}$ fluid barrier in patients with hepatic failure. American $\infty$ Journal of Medicine, 35, 350.

Morgan, T.N., Donald, I. \& MCANDREw, G.M. (1966)은 Muscle pain during therapy with Carbenoxolone (B gastrone). British Medical Journal, 2, 48.

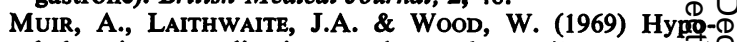
kalaemia complicating carbenoxolone (Duogastro色) therapy. British Medical Journal, 2, 512.

NutBouRNe, D.M. \& DE WARDENER, H.E. (1961) The effect of a water diuresis on the urinary excretion of hydrogen ions in man. Clinical Science, 20, 63.

PARKe, D.V. (1968) Metabolic studies with carbenoxolonefin man and animals. In: Symposium on Carbenoxolsige Sodium (Ed. by J. M. Robson \& F. M. Sullivan), pp. 15-24. Butterworth, London.

Pennington, R.J.T. (1969) Biochemical aspects of muscle disease. In: Disorders of Voluntary Muscle (Ed. by J. N.O Walton), 2nd edn, p. 393. Churchill, London.

Read, A.E., Laidlaw, J., Haslam, R.M. \& Sherlock, S. (1959) Neuropsychiatric complications following chloro- $\Rightarrow$ thiazide therapy in patients with hepatic cirrhosis; possible응 relation to hypokalaemia. Clinical Science, 18, 409.

RelmaN, A.S. \& SCHWARTZ, E.B. (1956) The nephropathy of potassium depletion. A clinical and pathological entity. New England Journal of Medicine, 255, 195.

Relman, A.S. \& SCHWARTZ, W.B. (1967). Effects of electro-을 lyte disorders on renal structure and functions. In: Rena?. Disease (Ed. by D. A. K. Black), 2nd edn, pp. 754-762. Blackwell Scientific Publications, Oxford.

RoussaK, N.J. (1952) Fatal hypokalaemic alkalosis with tetany during liquorice and PAS therapy. British Medical 3 Journal, 1, 360.

Salassa, R.M., Matrox, V.R. \& Rosevear, J.W. (1962)음 Inhibition of the 'Mineralocorticoid' activity of liquorice by spironolactone. Journal of Clinical Endocrine Meta-을 bolism, 22, 1156.

ShILs, M.E. (1969) Experimental human magnesium depletion. Medicine (Baltimore), 48, 61 .

SMith, W.O., BAXTER, D.J., LINDER, A. \& GiNN, H.E. (1962) N Effect of magnesium depletion on renal function in the rat.N Journal of Laboratory and Clinical Medicine, 59, 211.

Sodeman, W.A. \& ENGELHARDT, H.T. (1943) A renal concentration test employing posterior pituitary injection (Pitressin). Journal of the American Medical Association, (্) 122, 1070. 
StAmEY, T.A. (1956) The pathogenesis and implications of the electrolyte imbalance in ureterosigmoidostomy. Surgery, Gynaecology and Obstetrics, 103, 736.

STRONG, J.A. (1951) Serum potassium deficiency during treatment with sodium, PAS and liquorice extract. British Medical Journal, 2, 998.

TANNEN, R.L. (1969) The relationship between urinary pH and acid excretion; the influence of urine flow rate. Journal of Laboratory and Clinical Medicine, 74, 757.

TANNEN, R.S. (1970) The effect of uncomplicated potassium depletion in urine acidification. The Journal of Clinical Investigation, 49, 813.

Thomas, P.K. (1968) Diseases of muscles. In: Recent Advances in Medicine (Ed. by D. M. Baron, N. Compston \& A. M. Dawson), 15th edn, p. 46. Churchill, London.
De W ARdener, H.E. \& Herxheimer, A. (1957) Effect of high water intake on kidneys' ability to concentrate urine. Journal of Physiology, 139, 42.

WArren, K.S., Iber, E.L., Dolle, W. \& Sherlock, S. (1960) Effect of alterations in blood $\mathrm{pH}$ on distribution of ammonia from blood to cerebrospinal fluid in patients in hepatic coma. Journal of Laboratory and Clinical Medicine, 56, 687.

Welt, L.G., Hollander, W., Jr, \& Blythe, W.B. (1960) The consequences of potassium depletion. Journal of Chronic Diseases, 11, 213.

Wrong, O. \& Davies, H.E.F. (1959) The excretion of acid in renal disease. Quarterly Journal of Medicine, 28, 259.

\section{Hypokalaemic myopathy and myoglobinuria due to carbenoxolone sodium*}

\author{
P. C. BARNES \\ M.B., Ch.B.
}

\author{
J. H. C. LeONARD \\ M.D., F.R.C.P.
}

\section{University Hospital of South Manchester}

IN recent years it has become clear that the use of carbenoxolone sodium (Biogastrone, Duogastrone) may be accompanied by marked hypokalaemia (Turpie \& Thomson, 1965) in addition to retention of sodium, oedema and hypertension. Occasionally the depletion of potassium may be so severe as to cause muscular weakness (Mohamed, Chapman \& Crooks, 1966; Forshaw, 1969; Muir, Laithwaite \& Wood, 1969; Swallow, 1969; Fyfe, Cochran \& Begg, 1969). The patient described by Mohamed et al. also had myoglobinuria. So far as we can determine, the following patient is only the second example in which myoglobinuria has been confirmed following the use of carbenoxolone sodium.

\section{Case report}

A man, aged 75 years, was referred to the outpatient clinic on 23 July, 1969. He had previously been seen in 1962, at which time he had had intermittent abdominal pain for 20 years. A barium meal was normal in 1962, and again in 1966, and a barium enema was also normal in 1966. In January 1969, he lost his appetite and was given mist. mag. trisil. His dyspepsia persisted, and from the middle of May onwards his general practitioner gave him Biogastrone $50 \mathrm{mg}$ t.d.s. Six weeks later, he noticed pain in the back of both lower limbs, tiredness, and generalized muscular weakness. These symptoms became steadily more severe, and 1 week before he was seen he noticed that his urine was becoming dark.

\footnotetext{
* Request for reprints: University Hospital of South
} Manchester, Withington, Manchester, 20.
On examination, he looked unwell. The pulse rate was $60 / \mathrm{min}$, with long periods of coupled beats. The jugular venous pressure was normal, but there was moderate ankle oedema. The blood pressure was $170 / 100 \mathrm{mmHg}$. The heart sounds were normal. No abnormalities were noted in the lungs or abdomen. The upper limbs were normal. There was moderate weakness of the trunk muscles, and considerable weakness of the proximal muscle groups of both lower limbs; distally, the power was normal. All the tendon reflexes were virtually absent.

Investigations. The serum electrolytes are recorded in Table 1. The serum aldolase was 68 units $/ \mathrm{ml}$ (normal 3-12 units/ml) and the creatine phosphokinase was 310 units $/ \mathrm{ml}$ (normal 0-12 units $/ \mathrm{ml}$ ). The serum aspartate transaminase was 520 units $/ \mathrm{ml}$ and the serum alanine transaminase was 115 units $/ \mathrm{ml}$. Spectroscopy of the urine showed the presence of myoglobin. A 24-hr specimen of urine contained $0.66 \mathrm{~g}$ of creatinine and $46 \mathrm{mg}$ of creatine (within the normal range). The serum calcium was $8 \cdot 3 \mathrm{mg} / 100$ $\mathrm{ml}$, the serum inorganic phosphorus was $3.2 \mathrm{mg} / 100$ $\mathrm{ml}$, and the serum alkaline phosphatase was $15.5 \mathrm{KA}$ units. The electrocardiogram showed marked ST-T slurring characteristic of hypokalaemia. A muscle biopsy was reported as follows: 'The striated muscle shows focal areas of acidophilic muscle fibres surrounded by small collections of histiocytes. A few basophilic regenerating fibres are present. The blood vessels are normal. The appearances are those of a myopathy of metabolic or "steroid-induced" type' (Dr R. S. Whittaker). Electromyography was 